太田 剛史

高知医療センター脳神経外科

\title{
Telemedicine in Neurosurgery
}

\author{
Tsuyoshi Ohta, M.D., Ph.D.
}

Department of Neurosurgery, Kochi Health Sciences Center

Telemedicine refers to the provision of clinical services to patients in remote geographical locations via real-time bidirectional communication. Considering a sustainability based approach, telemedicine is important in Japan for effective delivery of health care services to local cities and remote regions. Optimization of treatment for acute cerebral stroke is an important component of neurosurgical services. Following advances in communication technology, real-time information sharing may become possible, particularly with regard to therapeutic procedures. This development would facilitate healthcare delivery at nighttime and during holidays when limited medical resources are available even in urban areas. Telemedicine would play an important role in the treatment of conditions that require a high level of diagnostic and therapeutic expertise. However, telemedicine also has the inherent shortcomings of medicine itself. When introducing and operating telemedicine, it is important to discuss the problems such as the scope of responsibility.

(Received October 8, 2019 ; accepted November 11, 2019)

Key words : telemedicine, neurosurgery, stroke

Jpn J Neurosurg (Tokyo) $29: 619-624,2020$

\section{はじめに}

2018 年の診療報酬改定で「オンライン診療料」「オン ライン医学管理料」が新設され，情報通信技術を活用し た新たな医療の機運が高まっている，本稿では遠隔医療 の背景と定義, 脳神経外科における遠隔医療の 2019 年 7 月現在の状況と問題点，地域遠隔医療システムの可能性 について検討する。

\section{遠隔医療の需要の背景}

2018 年 2 月 9 日の医療計画策定研修会における厚生労 働省医政局の資料 ${ }^{10)}$ によると, 「平成 20 年度以降, 医学
部定員を大幅に増員したが，医師の地域偏在・診療科偏 在は解消されて抢らず，地域・診療科によっては『医師 不足』との指摘」があることが問題視されている．その

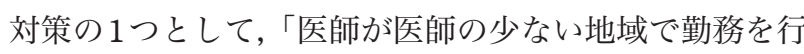
うに当たり, 不安を解消するための環境整備」として「医 師間の遠隔相談・骖療等に対する支援」が提案されてい る.

さらに，厚生労働省の医療政策の 1 つとして「医療分 野の情報化の推進」が挙げられ,「住み慣れた地域で安心 して質の高い医療サービスを受けながら生活していける ような社会を目指し，地域における医療機関等の間で必 要な情報連携を進めていくことは重要」で, 「ICT を活用 したネットワークを構築」し，「地域における質の高い医

連絡先：太田剛史， $=564-8565$ 大阪府吹田市岸部新町 6-1 国立循環器病研究センター脳神経外科

Address reprint requests to: Tsuyoshi Ohta, M.D., Ph.D., Department of Neurosurgery, National Cerebral and Cardiovascular Center, 6-1 Kishibe-shinmachi, Suita-shi, Osaka 564-8565, Japan 
療の提供に寄与する取組」が重視されている ${ }^{9)}$.

\section{遠隔医療の定義と現状}

遠隔医療とは，双方向性にやり取りした音声や視覚情 報をもとに，遠隔地の患者に対して行われる医療行為を いう。現状では，地方の医療の質の向上・患者の利便性 の向上・離島や僻地などにおける医療の地域差の是正な ぞ, 地域医療の充実の観点から重要と位置づけられてい $ろ^{9)}$.

厚生労働省の 2014 年医療施設調査では, 画像診断, 病 理診断，在宅医療が遠隔医療として行われていた。普及 に向け，厚生労働科学研究費補助金による研究助成，遠 隔病理診断・遠隔画像診断などに対する診療報酬上の評 価, 情報通信機器への補助事業, 医師等医療従事者に対 する研修事業などが実施されている.

\section{脳神経外科と遠隔医療}

遠隔医療であっても，「医師は，自ら診察しないで治療 をし（中略）てはならない」という医師法第 20 条との整 合性がなければならない，厚生省健康政策局長による平 成 9 年 12 月 24 日付の健政発第 1075 号では, 遠隔診療の 適正な実施を期するための留意事項が提示されてい $3^{11)}$ 。脳神経外科が遠隔医療を活用する場合は，急性期 診療のことが多いと思われるが，特に重要な項目を以下 に抜粋する.

(1)初診および急性期の疾患に対しては, 原則として直 接の対面診療によること

(2)離島，僻地の患者など直接の対面診療を行うことが 困難である場合には患者側の要請に基づき，患者側の利 点を十分に勘案したうえで，直接の刘面診療と適切に組 み合わせて行わ机るときは，遠隔診療によっても差し支 えないこと

(3)遠隔診療においても，直接の対面診療と同様，診療 の実施の責任は当然に診療を実施した医師が負うこと

(4)医師法第 20 条等における「診察」とは，問診，視 診，触診，聴診その他手段の如何を問わないが，現代医 学からみて, 疾病に対して一応の診断を下し得る程度の ものをいうこと

(5)直接の対面診療と同等ではないにしてもこれに代替 し得る程度の患者の心身の状況に関する有用な情報が得 られる場合には，遠隔診療を行うことは直ちに医師法第 20 条等に抵触するものではないこと

(6)特に医師を介在する遠隔医療，つまり医療機関と医
師相互間で行われる遠隔診療については，医師が患者と 対面して診療を行うものであり，医師法第 20 条との関 係の問題は生じないこと

以上から，遠隔診療がすべてを代用することはなく， あくまで直接の対面診療を補完するものとして考えられ ていることがわかる.

\section{脳神経外科における遠隔医療の現状と問題点}

遠隔医療による地方における急性期脳卒中診療の改善

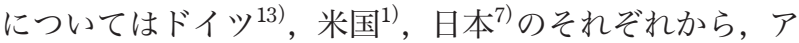
ルテプラーゼ静注療法の適応判断補助による適応拡大や 時間短縮の効果が報告されている。ささらに, 電話やFAX, 転送画像を用いてドクターヘリ内でアルテプラーゼ静注 療法を開始する試みも行わ机ている3 間の画像連携や電話でのやり取りに基づき急性期脳梗塞 に対する血管内治療の検討も広く行われている7 17)19).

実施にあたっては転送される情報の品質が保証されな ければならない。「オンライン診療」では医師-患者本人 間の情報通信機器を介した遠隔診療が認められている一 方，医師間，もしくは医師・医療者間の情報伝達におい ては，その専門性の高さからも2014 年 11 月 25 日に施行 された医薬品医療機器等法の認証を受けたプログラムが 必要とされている。同認証を受けたプログラムは依然限 られているが，今後のシステム構築では考慮しなければ ならない。

脳神経外科における遠隔医療の現状を鑑みると，上述 のような急性期脳卒中への応用が可能な施設は限られて いる，多くの施設ではまれな脳腫瘍などの診断が困難な 症例の画像デー夕を日常機器を使用して専門医に転送 し，診断・アドバイスを依頼することがすでに行われて いる。したがって，脳神経外科の多岐にわたる疾患にお いて，すでに一部の遠隔医療は実践されているが，医療 上のシステムとして確立するにはまだ時間を要するだろ う。また，一方向性伝達に伴う情報の不均衡や脳神経外 科で扱うような大容量データの転送の実用容量限界も懸 念される，さらに，身体状沉の把握，医師または医療者 の介在，往診または来診の困難というすべての条件を満 たす脳神経外科遠隔診療は，特に急性期診療の手段とし ては限定的である。すなわち，効率的な患者紹介・情報 提供以上の役割はないのが現状である.

\section{脳神経外科における今後の遠隔医療}

将来の遠隔医療では，介在する医師・医療職に詳細な 
知識がなくとも最適で迅速な診断・治療を実施できるよ うに，診療を専門的に補完することが望ましい．現在の 遠隔医療の条件では高い専門性を発揮することは難しい ため，新たな基準と法整備のほか双方向性の情報の同時 性・精度・容量を拡張しなければならない。近く普及が 期待される第 5 世代移動通信システム（5G）を介せば複 数の超精密なリアルタイム情報を低遅延での同時処理や 現実的な双方向伝達も期待できるため, 技術的な限界は 突破し得る。そうすると，大量の情報を短時間に処理・ 判断しつつ細密な手技を実施しなければならない脳神経 外科診療においても, 遠隔医療の実現可能性が出てく る，以下，法律的な限界はひとまず置いて，将来の遠隔 医療の技術的・倫理的側面について考察したい.

\section{地域遠隔医療システムの可能性}

「医療」は, どの検査を行うかの判断の基となる情報検 索である「診察」, 疾患のカテゴリー化, 病名決定のプロ セスである画像評価なぞの「診断」, 疾患の治癒, 軽快の ための方策である手術などの「治療」の 3 要素により構 成される。低遅延, 高速・大容量, 多接続を実現する近 未来の通信システムに基づく遠隔医療における, 各要素 の変貌を予想してみる。

近未来の遠隔「診察」においては, ヘッドマウントディ スプレイなどによる仮想現実的な視覚化, 小型化したド ローンによる遠隔地での多様な情報収集などを活用し て, 現実と同程度の身体情報を入手できるかもしれな い. 搬入前に救急隊の装着した機器を経由して実体験化 した診察ができるようになるかもしれない。その結果， 脳卒中, 特に主幹動脈閉塞患者の血栓回収脳卒中セン ターへの搬送など, 重症度や想定疾患に応じた特定機能 をもつ病院への誘導が可能となるかもしれない.

現時点でも脳神経外科領域の「診断」は画像所見に大 きく依存しているため，遠隔「診断」はもつとも現実的 である. CT/MRI などの画像を複数の医師がリアルタイ ムに評価できるようになれば，先の診察所見と複数の検 查所見を組み合わせて「診察」から「診断」までを連続 して短時間で実施可能だろう。救急医の診断を放射線科 医師がサポートすれば，医療上の間違いは減少すること もすでに報告 ${ }^{2)}$ れており，今後は各専門領域の診断の 正確性のためにこれらの補助は活用されるだろう。

電話などを介した断片的な情報に基づき上級医に治療 方針を相談したことはだれしもあるだろう。より精密な 情報を双方向性に伝達できれば，コンサルトする医師の 知識レベルに関係なく, 専門医が容易に判断できるよう
になるだろう。しかし，近未来の遠隔「治療」でそれ以 上に期待されるのは，双方向性を活用した「手技の遠隔 転送」であろう。現状では, 戦場で負傷した兵士を対象 に遠隔操作のロボット手術システムで迅速に処置するこ と ${ }^{15)}$ や, 循環器領域で離れたところでのカテーテル手技 である telestenting ${ }^{14)}$ はすでに試みられている。本邦で も, 2019 年 7 月一部改訂された「オンライン診療の適切 な実施に関する指針」では,「高度な技術を要するなど遠 隔地にいる医師でないと実施が困難な手術などを必要と し, かつ, 患者の体力面などから当該医師の下への般 送・移動等が難しい患者を対象」とした「情報通信機器 を用いた遠隔からの高度な技術を有する医師による手術 等」の項目が新設された ${ }^{8)}$. 新しい遠隔「治療」の影響 は大きく，地域ごとに「遠隔医療センター」を設置し， そこへの救急搬送を推進するような流れが生じれば，医 療の地域格差の解決につながるかもしれない.

具体的な例として, 以下に広域地方部での救急医療, 特に急性期血栓回収療法での遠隔医療の応用を考察す る。急性期血栓回収療法は前方循環閉塞の大半の患者で 利益があることが実証されており，主幹動脈閉塞患者に 対して迅速な治療開始を行うことができるような体制整 備が求められている4)。しかし，日本では地域間の治療 件数格差が大きく, 2016 年時点では最大で 10 倍を超え ていた ${ }^{20)}$. 特に地方では血栓回収療法を実施できる施設 が限られていることが背景因子としてあるかもしれな い. 本療法に遠隔医療システムが導入され，診断のため の情報転送およびカテーテル治療の技術送信が可能とな れば，転送に関係する判断や搬送という因子を省略する ことで大幅な時間短縮を達成できるかもしれない（Fig， 1)。そのためには，主幹動脈閉塞予測スケールを適応し て適切な患者を遠隔医療の可能な施設に搬送する tri$\mathrm{age}^{18)}$ や専門施設との連携方法と受け入れ態勢の整備な どの問題を解決しなければならないだろう。

以上より，地域遠隔医療システムにより，質の高い情 報をリアルタイムに共有することができるようになれ ば，地方，夜間，休日などの医療資源が手薄になる状況 でも，都市部の日中の豊富な医療体制を再現できるかも しれない。

\section{新しい遠隔医療の課題}

新しい遠隔医療が実現した近未来には，医療品質は向 上するかもしれない，同時並行的に発展するであろう artificial intelligence (AI) も実装されれば, 多くの画像診 断や一部の治療は人間のみの医療よりも優れた転帰をも 


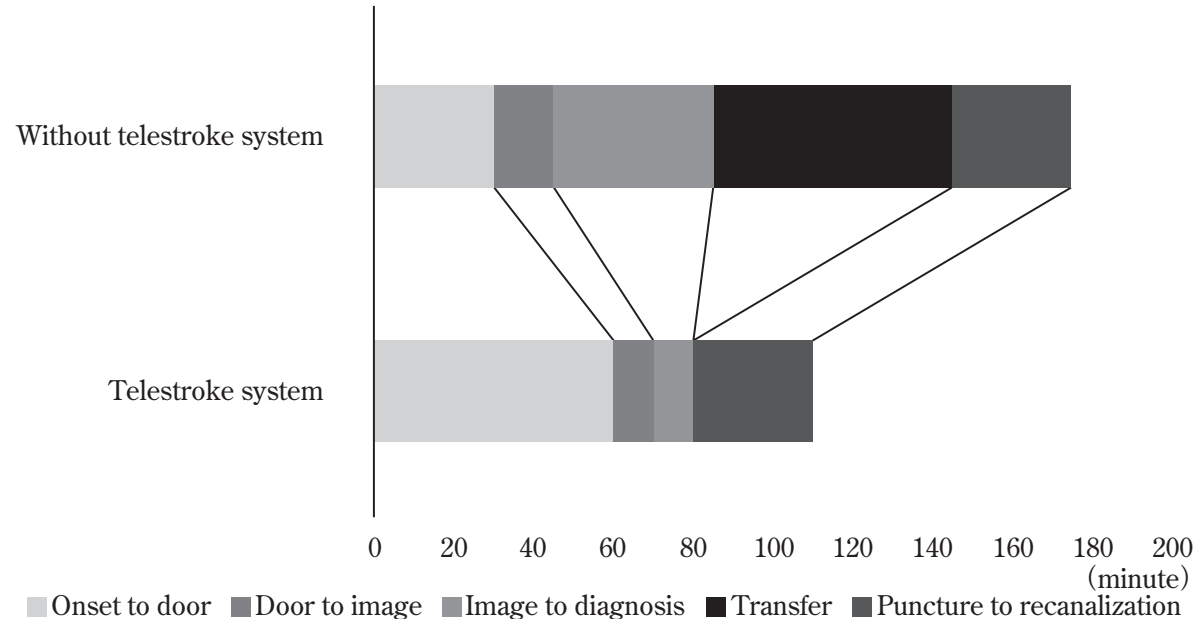

Fig. 1

たらすかもしれない ${ }^{12)}$. ただし，新しい遠隔医療にも固 有の課題が存在する.

第一の課題は情報通信の実装の段階的導入に関する問 題である. $5 \mathrm{G}$ ネットワークの構築には莫大な費用が必 要であり, 少なくとも当初は高速ワイヤレス通信へのア クセスに偏りが出るかもしれない ${ }^{16)}$ 。一般に通信機器は 人口の多い都市部から地方に広がるため, 遠隔医療を特 に必要とする地方でかえってそのメリットを享受する機 会が制限されるかもしれない。もし不十分な通信段階の 遠隔医療を推進すると，都市部と地方の地域格差が一見 解消されたようであっても，地方の中でメリット享受に 差が生じるかもしれない。つまり, 地方の中でも僻地で は医師などの不足による診療制限も通信機器の整備の遅 れもより高度であり，遠隔診療がそもそも導入できず, その結果地方内の医療格差が拡大してしまうかもしれな い. 中途半端な導入により最大の医療格差が僻地に集約 するという逆説を認識せず，誤った解釈に基づき僻地医 療が整理されると, 同地の医療過疎は悲惨な結果をもた らすだろう。情報通信制度のギャップを解消すること， 各地方での詳細な医療状況を把握することなどの対策が 必要である。

第二の課題は，医療のもつ不確実性に由来する。現実 の医療では，必要な情報を前もってすべて入手すること はできず，憶測の入り込む余地をもつ。そのため，遠隔 医療の進歩によって多様な情報を入手できるようになっ ても正確な診断や完全無欠な治療を常時達成することは 本質的に不可能である．欧米と比して契約の概念が希薄 な日本では, 医療過誤と予見される合併症とが同一視さ れがち ${ }^{21)}$ であり，理由を考慮せずに結果のみに対する責 任を求められることは今後もあるだろう。遠隔医療では
さらに，多数の医療者が関与し，診断・治療などに自律 した医療機器が介在することもあり得るため, 医療の実 施者が誰であるかも複雑になる。「オンライン診療の適 切な実施に関する指針」8) では「オンライン診療により医 師が行う診療行為の責任については, 原則として当該医 師が責任を負う」が,「䛦療の責任の主体は，原則として 従来から診療している主治医等の医師にあるが，情報通 信機器の特性を勘案し, 問題が生じた場合の責任分担等 についてあらかじめ協議しておくこと」と記載されてい

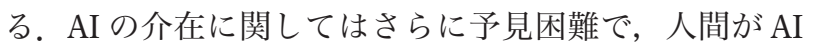
の操作に介入する手段がない完全自動運転の場合でも, 起こった事故に対してはその使用者が責任を問わ机るか もしれない6).いくら遠隔医療が技術として優れていて も, 関与によって理不尽な責任を取らされる可能性が高 いのであれば誰も利用しないだろう。専門的な診療を遠 隔地から実施することが普及すれば，その診療行為の責 任は現場の医師ではなく，遠隔医療を行った医師に求め られるようになるだろう。しかし，実際に医療事故が発 生した場合，その原因が遠隔医療を担当した医師の医療 行為なのか, 通信機器の異常なのか, 仲介した現場医師 の操作なのか, ヒトの介入できない $\mathrm{AI}$ なかを正確に区 別することは難しいだろう。過失の有無の判断を司法に 委ねるのは現場を萎縮させかねず，無過失補償などを制 度化すべきかもしれない5)。

医療の原点は直接の診察, 診断, 治療であり, 遠隔医 療の安易な運用は禁物であろう。

\section{結 語}

加速化する人口の地域偏在を見据え，地域医療格差の 
解決のために遠隔医療を導入することは必然である。現 状の遠隔医療は，慢性期の定型的診療における直接診療 の代理を想定したものであるが，次世代の通信システム により新しい診療が現実味を帯びており，特に治療転送 は脳神経外科の救急診療に変革をもたらすかもしれな い.しかし，遠隔医療の安易な導入と運用は避けるべき で，課題の理解と当事者意識の共有とが重要である.

\section{文 献}

1) Amorim E, Shih MM, Koehler SA, Massaro LL, Zaidi SF, Jumaa MA, Reddy VK, Hammer MD, Jovin TG, Wechsler LR: Impact of telemedicine implementation in thrombolytic use for acute ischemic stroke : the University of Pittsburgh Medical Center telestroke network experience. J Stroke Cerebrovasc Dis 22: 527-531, 2013.

2) Espinosa JA, Nolan TW : Reducing errors made by emergency physicians in interpreting radiographs: longitudinal study. BMJ $\quad 320: 737-740,2000$.

3）福田真紀，太田剛史，大西広一，松岡賢樹，岡田憲二， 政平訓貴, 津野隆哉, 森本雅徳：ドクターヘリを応用し た $\mathrm{rt}-\mathrm{PA}$ 早期投与のための地域間医療連携。Neurosurg Emerg 22:135-141, 2017.

4) Goyal M, Menon BK, van Zwam WH, Dippel DW, Mitchell PJ, Demchuk AM, Dávalos A, Majoie CB, van der Lugt A, de Miquel MA, Donnan GA, Roos YB, Bonafe A, Jahan R, Diener HC, van den Berg LA, Levy EI, Berkhemer OA, Pereira VM, Rempel J, Millán M, Davis SM, Roy D, Thornton J, Román LS, Ribó M, Beumer D, Stouch B, Brown S, Campbell BC, van Oostenbrugge RJ, Saver JL, Hill MD, Jovin TG ; HERMES collaborators : Endovascular thrombectomy after large-vessel ischaemic stroke: a meta-analysis of individual patient data from five randomised trials. Lancet 387 : 1723-31, 2016.

5）畑中綾子：医療事故無過失補償制度の論点一産科医療無 過失補償制度の議論に着目して。社会技術研究論文集 5: 122-131, 2008.

6) Hevelke A, Nida-Rümelin J : Responsibility for crashes of autonomous vehicles: an ethical analysis. Sci Eng Ethics 21: 619-630, 2015 .

7）本田省二, 甲斐 豊, 平野照之, 宇宿功市郎, 渡邊聖樹, 安東由喜雄, 倉津純一：スマートフォンを用いた脳卒中 遠隔医療態勢の構築一阿蘇モデル一。脳卒中 $36: 16^{-}$ 22, 2014.

8）厚生労㗢省：オンライン診療の適切な実施に関する指 針。平成 30 年 3 月. 2018 . https://www.mhlw.go.jp/con tent/10803000/000523501.pdf. (2019 年 7 月 31 日閲覧)

9）厚生労働省：医療分野の情報化の推進について. https:// www.mhlw.go.jp/stf/seisakunitsuite/bunya/kenkou iryou/ iryou/johoka/index.html（2019 年 7 月 31 日閲覧）
10）厚生労㗢省医政局：医師偏在対策について。平成 30 年 2 月 9 日. https://www.mhlw.go.jp/file/06-Seisakujo uhou-10800000-Iseikyoku/0000194394.pdf (2019 年 7 月 31 日閲覽）

11）厚生省健康政策局：情報通信機器を用いた診療（いわゆ る「遠隔診療」）について。健政発第 1075 号。平成 9 年 12 月 24 日 (平成 15 年 3 月 31 日拉よび平成 23 年 3 月 31 日 一部改正）https://www.mhlw.go.jp/bunya/iryou/ johoka/dl/h23.pdf（2019 年 7 月 31 日閲覧）

12) Lee EJ, Kim YH, Kim N, Kang DW : Deep into the brain : artificial intelligence in stroke imaging. J Stroke $19: 277-$ $285,2017$.

13) Müller-Barna P, Hubert GJ, Boy S, Bogdahn U, Wiedmann S, Heuschmann PU, Audebert HJ : TeleStroke units serving as a model of care in rural areas: 10-year experience of the TeleMedical project for integrative stroke care. Stroke 45:2739-2744, 2014.

14) Madder RD, VanOosterhout SM, Jacoby ME, Collins JS, Borgman AS, Mulder AN, Elmore MA, Campbell JL, McNamara RF, Wohns DH : Percutaneous coronary intervention using a combination of robotics and telecommunications by an operator in a separate physical location from the patient : an early exploration into the feasibility of telestenting (the REMOTE-PCI study). EuroIntervention 12: 1569-1576, 2017.

15) Martinic G: Glimpses of future battlefield medicine-the proliferation of robotic surgeons and unmanned vehicles and technologies. JMVH 22: 4-12, 2014.

16) Mims $C$ : The Downside of $5 \mathrm{G}$ : Overwhelmed Cities, TornUp Streets, a Decade Until Completion. The Wall Street Journal. https://www.wsj.com/articles/the-downside-of-5 g-overwhelmed-cities-torn-up-streets-a-decade-until-com pletion-11561780801（2019 年 6 月 30 日閲覧）

17）長内俊也：神戸宣言，その後：急性期脳梗塞に対する血 管内治療の普及の取り組み。各地方の取り組み 北海道 地区．脳血管内治療 4:7-13，2019.

18) Ohta $T$, Nakahara I, Matsumoto $S$, Kondo $D$, Watanabe $S$, Okada K, Fukuda M, Masahira N, Tsuno T, Matsuoka T, Takemura M, Fukuda H, Fukui N, Ueba T : Optimizing inhospital triage for large-vessel occlusion using a novel clinical scale (GAI2AA). Neurology 93: e1997-e2006, 2019.

19）進藤誠悟：神戸宣言，その後：急性期脳梗塞に対する血 管内治療の普及の取り組み。各地方の取り組み 九州地 方. 脳血管内治療 4:52-54, 2019.

20）高木俊範，吉村紳一，坂井信幸，飯原弘二，大石英則， 広畑 優，松丸祐司，松本康史，山上 宏：神戸宣言, その後：急性期脳梗塞に対する血管内治療の普及の取り 組み 全国の報告 全国調查の結果：RESCUE-Japan Project 2016. 脳血管内治療 $4: 2-6,2019$.

21）立嶋 智：UCLA Interventional Neuroradiology における 臨床活動。JNET 3:55-58，2009. 
脳神経外科と地域遠隔医療システムの可能性

太田 剛史

遠隔医療とは，双方向性の情報をもとに遠隔地の患者に対して行われる医療行為である．日本では 地方や僻地などの地域医療の充実の観点から重要とされる. 脳神経外科領域では急性期脳卒中診療の 適正化が報告されている. 今後の通信技術の発展次第では, 高品質情報をリアルタイムに共有して治 療手技も転送できるようになり，地方での夜間，休日などの医療資源が手薄になる状況下や高い専門 性が要求される疾患治療でも, 都市部の豊富な医療体制を再現できるようになるかもしれない. ただ し, 医療のもつ不確実性に由来する課題は残るため, 遠隔医療の導入と運用に際しては, 責任の所在 などについて当事者間で調整することが重要である.

脳外誌 $29 ： 619-624,2020$ 